University of Miami Law School University of Miami School of Law Institutional Repository

Articles

Faculty and Deans

2002

\title{
Fallen Superheroes and Constitutional Mirages: The Tale of Brady v. Maryland
}

Scott E. Sundby

University of Miami School of Law, ssundby@law.miami.edu

Follow this and additional works at: https://repository.law.miami.edu/fac_articles

Part of the Courts Commons, Criminal Procedure Commons, and the Law and Psychology Commons

\section{Recommended Citation}

Scott E. Sundby, Fallen Superheroes and Constitutional Mirages: The Tale of Brady v. Maryland, 33 McGeorge L. Rev. 643 (2002).

This Article is brought to you for free and open access by the Faculty and Deans at University of Miami School of Law Institutional Repository. It has been accepted for inclusion in Articles by an authorized administrator of University of Miami School of Law Institutional Repository. For more information, please contact library@law.miami.edu. 


\title{
Fallen Superheroes and Constitutional Mirages: The Tale of Brady v. Maryland
}

\author{
Scott E. Sundby*
}

\section{INTRODUCTION}

In the constitutional world of criminal procedure, a handful of Warren Court cases have taken on superhero status. Gideon, ${ }^{1}$ Miranda, ${ }^{2}$ Mapp, ${ }^{3}$ Duncan, ${ }^{4}$ and $K a t z^{5}$ are all cases in which the Court not only announced an important procedural right, but did so in ringing moral terms that forever associated the right with the case. These opinions possess special rhetorical power because they are expressly founded upon fundamental values like equality, human dignity, morality of government, protection of the oppressed, and privacy. Indeed, one suspects that the fervor with which decisions like Miranda and Mapp often are defended arises in part because of the sense that larger values and judgments are at stake.

This essay focuses on another criminal procedure superhero from the Warren Court, the case of Brady v. Maryland. ${ }^{6}$ Brady is often heralded as the Supreme Court case that granted the criminally accused a constitutional right to discovery. Like the other members of the pantheon, the Brady Court announced its holding with a strong tone of moral authority.

We now hold that the suppression by the prosecution of evidence favorable to an accused upon request violates due process where the evidence is material either to guilt or to punishment, irrespective of the good faith or bad faith of the prosecution. The principle ... is not punishment of society for misdeeds of a prosecutor but avoidance of an unfair trial to the accused. Society wins not only when the guilty are convicted but when criminal trials are fair; our system of the administration of justice suffers when any accused is treated unfairly. An inscription on

* Sydney and Frances Lewis Professor of Law, Washington \& Lee School of Law. This essay is based on a lecture given at the University of the Pacific, McGeorge School of Law as part of the McGeorge School of Law's Distinguished Speaker Series. I am grateful to Professors John Barrett, Frank Bowman, Darryl Brown, Joshua Dressler, William Geimer, Roger Groot, Dan Richman, Richard Seamon, Howard Srebnick, and George Thomas for their helpful comments on earlier drafts.

1. Gideon v. Wainwright, 372 U.S. 335 (1963).

2. Miranda v. Arizona, 384 U.S. 436 (1966).

3. Mapp v. Ohio, 367 U.S. 643 (1961).

4. Duncan v. Louisiana, 39 I U.S. 145 (1968).

5. Katz v. United States, 389 U.S. 347 (1967).

6. 373 U.S. 83 (1963). 
the walls of the Department of Justice states the proposition candidly for the federal domain: "The United States wins its point whenever justice is done its citizens in the courts."

From this Olympian perspective, Brady was the constitutional superhero that not only would ensure that a criminal defendant had access to all important exculpatory evidence before facing the State at trial, but also embodied the prosecutor's ethical duty to pursue "justice" and not simply victory in the courtroom.

Certainly when I first started teaching Brady, I taught it from this heroic viewpoint. To the extent that the criminal defense bar and legal commentators complained that exculpatory material was not forthcoming prior to trial, I attributed such failures not to Brady, but to prosecutors failing to live up to their constitutional duties. Lately, however, I have begun to wonder whether, like my childhood heroes, Brady is not the constitutional superhero that I once thought. ${ }^{8}$

This essay examines the failed promise of Brady and argues that while Brady undoubtedly sets forth an important constitutional right, its significance lies primarily outside the realm of pre-trial discovery. In other words, if anyone else has shared the belief that Brady sets forth an important constitutional right for discovering exculpatory evidence prior to trial, it is time that we re-examine Brady and realize that its superhero powers are far more limited. In fact, although it sounds provocatively odd to state, I will suggest that under the Court's current Brady doctrine, an ethical prosecutor arguably should never be in the position of turning over Brady material prior to trial.

Before that last statement triggers an avalanche of outraged comments, let me make clear that this essay is not an apologia for prosecutors who fail to turn over important discovery material to the defense. Rather, the essay's purpose is to highlight the point that if academia, the courts, and lawyers are pointing to Brady as a means of ensuring that defendants are receiving "favorable" evidence prior to trial, they are largely pointing to a mirage. ${ }^{9}$ While part of the difficulty may be that some prosecutors are not fulfilling their duties under Brady, this essay suggests that a significant part of the problem also lies with the Supreme Court's decisions: the Court's development of Brady's holding destined the doctrine to become less of a pre-trial discovery right and more of a post-trial remedy for prosecutorial and law enforcement misconduct.

\section{Id. at 87 .}

8. Such a reassessment perhaps should not be limited to Brady. Commentators increasingly are calling into question the continued viability of the Supreme Court's landmark decisions in the criminal procedure area. See, e.g., William J. Stuntz, The Uneasy Relationship Between Criminal Procedure and Criminal Justice, 107 YALEL.J. 1 (1997).

9. The mirage metaphor has occurred to at least one other commentator writing about Brady. See M. Shawn Matlock, The Mirage of Brady in Wyoming: How Far Will the Wyoming Supreme Court Allow a Prosecutor to Go?, 35 LAND \& WATER L. REV. 609 (1999). 
Now, it may be that most lawyers, judges, and legal observers never fell under Brady's constitutional spell and did not believe that the case possessed significant discovery powers. To the extent that Brady's mystique has transfixed others, however, the danger exists that a Brady mirage is obscuring a clear-eyed evaluation of whether current discovery standards are effectively granting defendants access to exculpatory evidence. In other words, if we do not expressly recognize Brady's limitations as a discovery doctrine, we may erroneously be tempted to dismiss or downplay complaints that discovery rules are inadequate because of a misguided belief that Brady ultimately will ensure that nothing important slips through. This essay's bottom-line message, therefore, is that if Brady provides a sense of security that defendants are constitutionally entitled to broad discovery, that sense of security is a false one. If there is legitimacy to the arguments that defendants should receive broad discovery (and I do not attempt to resolve that debate in this essay), then either Brady must be dramatically altered or the criminal justice system must turn to other avenues to accomplish that goal, avenues such as statutory discovery rights and the rules of criminal procedure.

\section{THE EVOLVING MATERIALITY STANDARD AND THE FALLEN SUPERHERO}

In Brady, the Court announced "that the suppression by the prosecution of evidence favorable to an accused upon request violates due process where the evidence is material either to guilt or to punishment, irrespective of the good faith or bad faith of the prosecution." In the ensuing decades, the Court has built upon this standard and extended Brady's reach to include impeachment evidence," evidence that the defendant has not specifically requested, ${ }^{12}$ and evidence that is in the control of government actors other than the prosecutor. ${ }^{13}$ Examined in the light of these cases, Brady appears to be an expanding doctrine into which the Court has injected flexibility to reflect the realities of criminal prosecutions.

As Brady's scope has been expanding to cover a broader range of government behavior and evidence, however, the Court simultaneously has been contracting the Brady right on another front, that of materiality. The Court's decisions defining what constitutes "material" evidence are particularly important because they have changed the very nature of how Brady operates in practice. Indeed, it is the Court's materiality decisions that essentially have robbed Brady of any pre-trial superhero powers and transformed the doctrine from a pre-trial discovery right into a post-trial remedy for government misconduct. Thus, while

\footnotetext{
10. 373 U.S. at 87.

11. United States v. Bagley, 473 U.S. 667, 676 (1985).

12. United States v. Agurs, 427 U.S. 97, 107 (1976).

13. Kyles v. Whitley, 514 U.S. 419,438 (1995).
} 
the breadth of Brady's coverage may have expanded to cover matters like impeachment evidence, that expansion is somewhat illusory because the compass of impeachment evidence that actually would qualify as material under Brady is now so circumscribed.

To understand the role of materiality in shaping Brady, it is helpful to briefly retrace how the Court arrived at the current definition of what constitutes material Brady evidence. Recall the basic standard that Brady announced: "[T]he suppression by the prosecution of evidence favorable to an accused upon request violates due process where the evidence is material either to guilt or to punishment, irrespective of the good faith or bad faith of the prosecution." If one goes back and reads Brady, it is a little surprising to find that while the adjective "material" is used to describe the evidence which is covered by the new right, no definition of what constitutes "material" is given.

Indeed, one perfectly plausible reading of "material" within the context of the opinion is that it means "relevant," such that the prosecution would be obligated to turn over all relevant favorable evidence. ${ }^{15}$ At one point in his Brady opinion, for instance, Justice Douglas stated the obligation in words that resonate with the idea of relevance: "A prosecution that withholds evidence on demand of an accused which, if made available, would tend to exculpate him or reduce the penalty helps shape a trial that bears heavily on the defendant." ${ }^{16}$ Moreover, without any signal of disapproval, the Brady majority opinion quoted the state court's rationale for reversing Brady's death sentence, a rationale that suggests a relatively low materiality standard for reversal:

There is considerable doubt as to how much good [the co-defendant's] undisclosed confession would have done Brady if it had been before the jury. It clearly implicated Brady as being the one who wanted to strangle the victim, Brooks. [The co-defendant], according to this statement, also favored killing him, but he wanted to do it by shooting. We cannot put ourselves in the place of the jury and assume what their views would have been as to whether it did or did not matter whether it was Brady's hands or [the co-defendant's] hands that twisted the shirt about the victim's neck.... It would be 'too dogmatic' for us to say that the jury would not have attached any significance to this evidence in considering the punishment of the defendant Brady.

14. 373 U.S. at 87.

15. Justice Marshall made a similar observation in his dissent in Bagley, 473 U.S. at 703 n.5 (Marshall, J., dissenting) (pointing to case citations within the Brady opinion that "provide strong evidence that Brady might have used the word [material] in its evidentiary sense, to mean, essentially, germane to the points at issue."). See also Strickler v. Greene, 527 U.S. 263, 298 (1999) (Souter, J., dissenting) ("Brady itself did not explain what it meant by 'material' (perhaps assuming the term would be given its usual meaning in the law of evidence ....)"); United States v. Coppa, 267 F.3d 132, 141 (2d Cir. 2001) ("IT] he [Brady] Court appears to be using the word 'material' in its evidentiary sense, i.e., evidence that has some probative tendency to preclude a finding of guilt or lesser punishment, $c f$. Fed. R. Evid. 401.").

16. Brady, 373 U.S. at $87-88$ (emphasis added). 
Not without some doubt, we conclude that the withholding of this particular confession of [the co-defendant] was prejudicial to the defendant Brady. ${ }^{17}$

Finally, while the Court agreed with the state court that Brady was entitled only to a new sentencing hearing and not to a new guilt trial, its reasoning was not that the co-defendant's confession would have had no material effect on the jury's guilty verdict, but that the confession would have been inadmissible at the guilt trial under state law. ${ }^{18}$ The Court's holding, therefore, while not expressly embracing a relevance standard, was consistent with the idea that the exculpatory evidence simply had to be relevant (and admissible) to be material.

If the Brady doctrine had eventually grown into this interpretation, then the doctrine very well may have taken on the heroic qualities that I once attributed to it. And there was a voice on the Supreme Court arguing for such a vision. Justice Marshall maintained that if Brady was to fulfill its due process aspirations of ensuring that a defendant had a fair chance of meeting the State's allegations, then the State must be required to turn over "all information ... that might reasonably be considered favorable to the defendant's case."19 This view, as we will see, would likely have turned Brady into a far more vibrant channel of pretrial discovery.

Instead, the Court ultimately rejected the heroic view through a series of decisions that gradually defined Brady's materiality requirement with increasing strictness. As noted before, this gradual contraction of Brady's reach was often partially masked because it took place in cases where the Court was at the same time extending Brady's applicability to new fact situations. With the benefit of hindsight, we can trace how Brady became more of a post-trial remedy than a pre-trial discovery right.

The process began with United States v. Agurs,$^{20}$ decided thirteen years after Brady. The case reflects precisely the phenomenon of the Court expanding Brady's reach to new situations, while at the same time narrowly circumscribing through the materiality requirement the actual evidence which becomes subject to discovery. In Agurs, the Court for the first time expressly held that Brady extended to exculpatory evidence even if the defendant had not specifically requested the evidence. ${ }^{21}$ However, bringing such evidence within Brady's coverage also necessarily raised a question that brought materiality to the fore: if no defense request is necessary to trigger Brady, how is a prosecutor in reviewing her file to know

17. Id. at 88 (emphasis omitted). While the Court's use of the state court's language is consistent with a relevance-based definition of materiality, fairness requires acknowledgment that the Court was not using the quotation to explain materiality. Rather, it was using the quotation as a prelude to explaining why even if the evidence might be material under Maryland's law, the confession would have been inadmissible at the guilt trial, so Brady was entitled only to a new sentencing hearing.

18. Id. at 90 .

19. Bagley, 473 U.S. at 695-96 (Marshall, J., dissenting).

20. 427 U.S. 97 (1976).

21. Id. at 97 . 
what evidence she must turn over to avoid constitutional sanctions? In Agurs, the Supreme Court understood the lower court's opinion as essentially holding that prosecutors must turn over any evidence that "might affect the jury's verdict"-a standard that the Court believed for all practical purposes would mean that "the only way a prosecutor could discharge his constitutional duty would be to allow complete discovery of his files as a matter of routine practice.",22

While the Court encouraged "prudent prosecutor[s to] resolve doubtful questions in favor of disclosure, ${ }^{, 23}$ it also firmly clarified that Brady disclosure was not a discovery right as such ${ }^{24}$ but an obligation that dealt "with the defendant's right to a fair trial mandated by the Due Process Clause., ${ }^{25}$ While tacitly acknowledging that the original Brady opinion was ambiguous in its intended use of the word "material," "material" with "relevant." The Court stated that "the prosecutor will not have violated his constitutional duty of disclosure unless his omission is of sufficient significance to result in the denial of the defendant's right to a fair trial." ${ }^{27}$ The opinion later made clear that "of sufficient significance" means that "the omitted evidence creates a reasonable doubt that did not otherwise exist.",28

In crafting its materiality standard, the Agurs majority was attempting to ensure that prosecutors would not run afoul of Brady simply because they did not turn over all of the government's evidence to the defendant. This concern was highlighted because Agurs was formally extending Brady to information about which the prosecutor did not have "notice" from the defendant that it might be important. By contrast, in prior Brady cases, the prosecutor had been on notice because the defendant had specifically requested the information, ${ }^{29}$ or because the prosecutor realized or should have known that perjured testimony was being presented at trial一a situation that involved such "fundamental unfairness" that any prosecutor would be aware of the need to take corrective action. ${ }^{30}$ Where a

22. Id. at 108-09.

23. Id. at 108 .

24. Id. at 107 ("We are not considering the scope of discovery authorized by the Federal Rules of Criminal Procedure, or the wisdom of amending those Rules to enlarge the defendant's discovery rights.").

25. Agurs, 427 U.S. at 107.

26. In Agurs, Justice Stevens seemed to acknowledge the potential ambiguity when he stated: "A fair analysis of the holding in Brady indicates that implicit in the requirement of materiality is a concern that the suppressed evidence might have affected the outcome of the trial." Id. at 104 (emphasis added).

27. Id. at 108 .

28. Id. at 112. The Court also stated, however, that the defendant need not demonstrate that the suppressed evidence "probably would have resulted in acquittal," the standard for a new trial based on newly discovered evidence. $I d$. at 111 . The Court reasoned that not requiring this extra step provided recognition of the "special significance" that the evidence had been in the government's possession and was not found in a "neutral source." Id. Justice Marshall in his dissent could not see the difference, since "[s]urely if a judge is able to say that evidence actually creates a reasonable doubt as to guilt in his mind (the Court's standard), he would also conclude that the evidence 'probably would have resulted in acquittal."' $I d$. at 116 (Marshall, J., dissenting).

29. Brady's attorney specifically asked to see any statements by the co-defendant.

30. The perjury line of cases significantly predates the Brady decision. See, e.g., Mooney v. Holohan, 294 U.S. 103 (1935). However, it is now characterized as a type of Brady violation. Agurs, 427 U.S. at 103. 
specific request has not been made, however, the majority reasoned that the notice to the prosecutor of the need to turn information over must come from the nature of the exculpatory evidence itself: "[I]f the evidence is so clearly supportive of a claim of innocence that it gives the prosecution notice of a duty to produce, that duty should equally arise even if no request is made." ${ }^{\prime 31}$

While the Agurs Court's concern over "notice" led it to adopt a stringent definition of materiality for cases where the defendant had made no request or only a general request, it indicated that a more lenient standard would apply to specific request cases because "[w]hen the prosecutor receives a specific and relevant request, the failure to make any response is seldom, if ever, excusable." ${ }^{32}$ In United States v. Bagley, ${ }^{33}$ however, the Court moved even further in characterizing Brady's materiality standard as merely one aspect of the Court's general "fair trial" right rather than treating it as a constitutional obligation with a distinct lineage. Relying on opinions dealing with ineffective assistance of counsel and unavailable defense witnesses, ${ }^{34}$ the Bagley Court announced that a one-size-fitsall materiality standard would now govern Brady cases, regardless of whether the defendant had made a specific request, a general request, or no request at all: "The evidence is material only if there is a reasonable probability that, had the evidence been disclosed to the defense, the result of the proceeding would have been different. A 'reasonable probability' is a probability sufficient to undermine confidence in the outcome. ${ }^{, 35}$ In the later case of Kyles $v$. Whitley, ${ }^{36}$ the Court placed a further functional gloss on the meaning of "reasonable probability" by stating that the question is whether "the favorable evidence could reasonably be taken to put the whole case in such a different light as to undermine confidence in the verdict. ${ }^{37}$

The extent of Bagley's movement towards a "result-focused" standard ${ }^{38}$ for determining whether Brady had been violated was driven home in Strickler v. Greene. ${ }^{39}$ While the Court did not alter the test for materiality, the majority opinion seemed aware that a perception had arisen that Brady compelled a prosecutor to turn over important exculpatory evidence even if the evidence

31. Agurs, 427 U.S. at 107.

32. Id. at 106 .

33. 473 U.S. 667 (1985)

34. See United States v. Valenzuela-Bernal, 458 U.S. 858 (1982) (due process is violated when testimony is made unavailable through government deportation of a defense witness); Strickland $\mathrm{v}$. Washington, 466 U.S. 668 (1984) (ineffective assistance of counsel requires reversal when outcome reliability is undermined). Strickland, in turn, relied upon Agurs in defining its reversal standard. Id. at 694.

35. Bagley, 473 U.S. at 682. The Bagley majority apparently envisioned that a lower standard of materiality would continue to apply to the prosecution's use of perjured testimony because of its seriousness as "a corruption of the truth-seeking function of the trial process." Id. at 680 (quoting Agurs, 427 U.S. at 104). In the perjured testimony category, the evidence is "considered material unless failure to disclose it would be harmless beyond a reasonable doubt." Id.

36. 514 U.S. 419 (1995).

37. Id. at 435 .

38. Bagley, 473 U.S. at 714 (Stevens, J., dissenting).

39. 527 U.S. 263 (1999). 
would not by itself undermine the verdict. The Court thus went out of its way to distinguish "so-called Brady violations" from "true Brady violation[s]."

[T] he term "Brady violation" is sometimes used to refer to any breach of the broad obligation to disclose exculpatory evidence-that is, to any suppression of so-called "Brady material"-although, strictly speaking, there is never a real "Brady violation" unless the nondisclosure was so serious that there is a reasonable probability that the suppressed evidence would have produced a different verdict. There are three components of a true Brady violation: The evidence at issue must be favorable to the accused, either because it is exculpatory, or because it is impeaching; that evidence must have been suppressed by the State, either willfully or inadvertently; and prejudice must have ensued. ${ }^{40}$

Consequently, although the government had not disclosed powerful impeachment evidence in Strickler, ${ }^{41}$ the majority concluded that a Brady violation had not occurred because the "petitioner ha[d] not shown that there [was] a reasonable probability that his conviction or sentence would have been different had these materials been disclosed." ${ }^{42}$

\section{The Materiality STANDARd MeETS the ETHICAL ProseCUtor}

While the Court's emphasis in Strickler on clarifying what constitutes "true" Brady material did not change the law, it does effectively highlight a largely unexplored tension between Brady and the prosecutor's ethical duties. The Court's clarification between "true" Brady and "so-called" Brady material seems to be aimed at guarding against "ethical creep"-the temptation to use ethical norms to define the constitutional standard regulating discovery. In other words, the Court seems to be saying that a distinction must be maintained between what is ethically desirable as prosecutorial discovery and what is constitutionally required.

This position does have a bit of an odd feel to it given that the Brady opinion itself reminded prosecutors in thunderous tones that their duty is "not to achieve victory but to establish justice., ${ }^{, 43}$ Since Brady, however, the Court has

40. Id. at $281-82$ (footnote omitted).

41. The Court rejected the Fourth Circuit's cursory characterization of the disputed impeachment evidence as "provid|ingl little or no help." Id. at 289. The majority, however, found that, at most, the impeachment evidence created a "reasonable possibility" of a different result rather than the requisite "reasonable probability." $I d$. at 290-91

42. Id. at 296. The dissent believed that the suppressed impeachment evidence created a reasonable probability that a different sentencing verdict, a life rather than a death sentence, would have resulted. Justice Souter also proposed restating the materiality standard in terms of a "significant possibility" rather than "reasonable probability," because of his belief that the "term 'probability' raises an unjustifiable risk of misleading courts into treating it as akin to the more demanding standard, "more likely than not."' Id. at 298 (Souter, J., concurring and dissenting).

43. Brady, 373 U.S. at 87 n.2. 
consistently cautioned that Brady's discovery obligation does not stretch as far as a prosecutor's ethical duty. Recall that the Agurs Court emphasized that it was not going to allow Brady to be used as a means of smuggling a de facto open-file policy into the Constitution. ${ }^{44}$ More pointedly, in Kyles, the Court expressly acknowledged that, "the rule in Bagley (and, hence, in Brady) requires less of the prosecution than the ABA Standards for Criminal Justice, which call generally for prosecutorial disclosures of any evidence tending to exculpate or mitigate." This refusal to extend Brady's constitutional obligation as far as the prosecutor's ethical duties is not unusual, of course, as the Court frequently admonishes that constitutional duties are to be interpreted independently of what might constitute wise or desirable public policy. ${ }^{46}$

Yet, while the untying of the constitutional standard from underlying ethical norms is not particularly remarkable, it is still important to ask what Brady means for the ethical prosecutor. This is especially true because Brady, despite the Court's later attempts at severance, remains intimately associated in both legal and public minds with notions of prosecutorial ethics. And if we undertake this inquiry of what Brady asks of the ethical prosecutor, the answer is quite interesting and perhaps a bit startling.

Let us conduct the inquiry by placing our prosecutor in a pre-trial situation where she receives a piece of evidence that she must evaluate under the Court's materiality standard. For the Brady obligation to be triggered, she would have to hold the evidence in her hand and think:

This piece of evidence is so exculpatory in nature that it actually undermines my belief that a guilty verdict would be worthy of confidence. Under Brady, therefore, I need to turn this evidence over to the defense. Then, once I turn the evidence over and satisfy my constitutional obligation, I can resume my zealous efforts to obtain a guilty verdict that I have just concluded will not be worthy of confidence.

Viewed through this scenario, the Court has set Brady's materiality threshold at a point where we should be raising an ethical eyebrow at the prosecutor who actually declares that she has "true" Brady material that she must turn over to the defense. If the Court's materiality standard is taken literally, far from indicating that we are dealing with an ethical prosecutor, a prosecutor turning over Brady

44. Agurs, 427 U.S. at 109.

45. Kyles, 514 U.S. at 437 (citing ABA STANDARDS FOR CRIMINAL JUSTICE, PROSECUTION FUNCTION AND DEFENSE FUNCTION 3-3.1 I (a) (3d ed. 1993); MODEL RULES OF PROF'L CONDUCT R. 3.8(d) (1984)).

46. See, e.g., Strickland, 466 U.S. at 688 ("Prevailing norms of practice as reflected in American Bar Association standards and the like ... are guides to determining what is reasonable, but they are only guides."); United States v. Ash, 413 U.S. 300, 320-2l (1973) ("The primary safeguard against abuses of [photo arrays] is the ethical responsibility of the prosecutor. ...We are not persuaded that the risks inherent ... are so pernicious that an extraordinary system of safeguards is required."); Cuyler v. Sullivan, 446 U.S. 335, 346 n. 10 (1980) (although the Sixth Amendment does not require state trial judges to inquire about conflicts-of-interest where multiple representation exists, "[a]s our promulgation of Rule 44(c) [of the Federal Rules of Criminal Procedure] suggests, we view such an exercise of the supervisory power as a desirable practice."). 
evidence should make us pause and wonder: why is she still pursuing prosecution after acknowledging that evidence exists creating a reasonable probability that an innocent defendant may be convicted? Is not the prosecutor who turns over Brady evidence prior to trial, therefore, identifying herself as precisely the type of prosecutor condemned by the Brady Court as someone more interested in "achiev[ing] victory" than "establish[ing] justice?"

It is in this sense that I suggested at the essay's beginning that if the Court is serious about its materiality standard for Brady, then arguably an ethical prosecutor should never have Brady material to turn over to the defense. Instead, a conscientious prosecutor faced with "true" Brady evidence-material so exculpatory that it would make her question the reliability of a guilty verdict-should move for dismissal of the charges that no longer are supported by the evidence.

Several possible responses come to mind. First, the ABA standards ethically allow a prosecutor to proceed with a prosecution supported only by probable cause. ${ }^{47}$ Under these standards, a prosecutor could find "true" Brady material and still proceed, confident that the case has not fallen below the probable cause standard needed for indictment. Without attempting to indict the ABA rule itself, ${ }^{48}$ I would suggest that even a believer in the ABA probable cause threshold would have serious ethical pangs as she zealously asked a jury to convict someone about whom she entertained serious doubts as to his or her guilt. More subjectively, I would argue that most prosecutors generally do wish to pursue "justice" rather than "victory," and "justice" would not include convicting an individual about whom they harbor serious doubts as to guilt. Consistent with this view, prosecutorial guidelines, such as the U.S. Attorneys' Manual, call for the prosecutor to evaluate the strength of the evidence as measured against the reasonable doubt standard and not that of probable cause. ${ }^{49}$

Moreover, even if one takes a less charitable view of prosecutorial motives and sees prosecutors as primarily motivated by the desire for victory, a prosecutor

47. ABA STANDARDS FOR CRIMINAL JUSTICE, PROSECUTION FUNCTION 3-3.9(a) (3d ed. 1993) ("A prosecutor should not institute, or cause to be instituted, or to permit the continued pendency of criminal charges when the prosecutor knows that the charges are not supported by probable cause.").

48. Interestingly, after setting out the probable cause standard, the ABA standard appears to back away from using probable cause to justify prosecution, stating that "[a] prosecutor should not institute, cause to be instituted, or permit the continued pendency of criminal charges in the absence of sufficient admissible evidence to support a conviction." Id. The ABA standards also provide that "[a] prosecutor should not be compelled by his or her supervisor to prosecute a case in which he or she has a reasonable doubt about the guilt of the accused." Id. 3-3.9(c).

49. The U.S. Attorneys" Manual recognizes that "[t]he probable cause standard is ... a threshold consideration only. Merely because this requirement can be met in a given case does not automatically warrant prosecution; further investigation may be warranted, and the prosecutor should still take into account all relevant considerations, including those described in the following provisions." U.S. ATTYS' MANUAL 9-27.200 cmt. (U.S. Dep't of Justice 2002). The Manual proceeds to state that "both as a matter of fundamental fairness and in the interest of the efficient administration of justice, no prosecution should be initiated against any person unless the government believes that the person probably will be found guilty by an unbiased trier of fact." $I d$.

9-27.220 cmt.; see also STANDARDS FOR NAT'L PROSECUTION (Nat'l Dist. Attys' Ass'n., 2d ed. 1991) (amended 1999) ("The prosecutor shall file only those charges which he believes can reasonably be substantiated by admissible evidence at trial."). 
faced with "true" Brady evidence in our scenario would be likely to seek dismissal of the charges. Prosecutors evaluating a case are acutely aware that eventually the case must be proven beyond a reasonable doubt, ${ }^{50}$ and while it may be possible to indict a ham sandwich before a grand jury with a probable cause standard, convicting a defendant on evidence beyond a reasonable doubt before a petit jury is a far more daunting task. As every prosecutor knows, it is a rare case that does not develop unanticipated weaknesses or holes (like the key witness who suddenly becomes inarticulate on the witness stand). To proceed to trial knowing that the defense is already armed with powerful exculpatory evidence, therefore, would seem to be inviting an adverse verdict. And while prosecutors may foremost be "ministers of justice," their reputation (or lack thereof) as successful trial attorneys is likely to have an impact on professional advancement within the prosecutor's office or on the later availability of opportunities in the private sector.

There is, however, another scenario which theoretically would allow the prosecutor to adhere to an ethical standard that requires her to believe that the defendant is guilty beyond a reasonable doubt while still turning over "true" Brady material. This prosecutor could look at evidence and have the following internal monologue:

I can see how a trier of fact might take this piece of evidence in such a way as to disbelieve my key witness, which would likely then lead them to find a reasonable doubt. Now, I certainly believe the witness, and I think that I can convince the jury that he is telling the truth because of the evidence corroborating his testimony. Still, I could see how if the jury did not hear this evidence, a court later could say that because the jury didn't have a chance to consider the impeaching evidence, the reliability of the guilty verdict is undermined. Therefore, this is true Brady material and I must turn it over.

This prosecutor, then, would appear to satisfy both the ethical mandate of pursuing only cases in which she believes in the defendant's guilt while also finding "true" Brady material to disclose.

If this is the only scenario that allows us to find ethical prosecutors who will be turning over "true" Brady material prior to trial, however, we have identified a narrow band of cases indeed. First, the thought process posits a prosecutor who is

50. Cf. U.S. ATTYS' MANUAL $9-27.300 \mathrm{cmt}$.

At the outset, the attorney for the government should bear in mind that at trial he/she will have to produce admissible evidence sufficient to obtain and sustain a conviction or else the government will suffer a dismissal. For this reason, he/she should not include in an information or recommend in an indictment charges that he/she cannot reasonably expect to prove beyond a reasonable doubt by legally sufficient evidence at trial.

ld.

51. MODEL RULES OF PROF'L CONDUCT R. $3.8 \mathrm{cmt}$. (2002); see also Berger v. United States, 295 U.S. $78,88(1935)$. 
capable of a Zen-like state of harmonizing objective and subjective beliefs, simultaneously recognizing that the evidence objectively creates a reasonable probability that a reasonable jury will entertain a reasonable doubt while still subjectively believing that continued prosecution is warranted. Justice Marshall, in particular, believed that asking prosecutors to make such a "dual" assessment was to ignore "the realit[ies] of criminal practice:",52

At the trial level, the duty of the state to effectuate Brady devolves into the duty of the prosecutor; the dual role that the prosecutor must play poses a serious obstacle to implementing Brady. The prosecutor is by trade, if not necessity, a zealous advocate. He is a trained attorney who must aggressively seek convictions in court on behalf of a victimized public. At the same time, as a representative of the state, he must place foremost in his hierarchy of interests the determination of truth. Thus, for purposes of Brady, the prosecutor must abandon his role as an advocate and pore through his files, as objectively as possible, to identify the material that could undermine his case. Given this obviously unharmonious role, it is not surprising that these advocates oftentimes overlook or downplay potentially favorable evidence, often in cases in which there is no doubt that the failure to disclose was a result of absolute good faith. ...

The prosecutor surely greets the moment at which he must turn over Brady material with little enthusiasm. In perusing his files, he must make the often difficult decision as to whether evidence is favorable, and must decide on which side to err when faced with doubt. In his role as advocate, the answers are clear. In his role as representative of the state, the answers should be equally clear, and often to the contrary. Evidence that is of doubtful worth in the eyes of the prosecutor could be of inestimable value to the defense, and might make the difference to the trier of fact. ${ }^{53}$

52. Justice Marshall's emphasis on "the realities of criminal practice" is consistent with his general emphasis on the necessity of recognizing that the Court's holdings would be implemented in the real world: "His legal positions, . . . seem to have been rooted, not in any overarching ideology of limited government, but in an intense awareness, based upon long experience, that those who wield the authority of the state are but human actors." Bruce A. Green \& Daniel Richman, Of Laws and Men: An Essay on Justice Marshall's View of Criminal Procedure, 26 ARIZ. ST. L.J. 369, 370 (1994). For a penetrating look at the realities of how federal prosecutors exercise their discretion, especially in relation to interacting with agents, see Daniel Richman, Prosecutors and Their Agents-Agents and Their Prosecutors (forthcoming) (on file with the author).

53. Bagley, 473 U.S. at 696-98 (Marshall, J., dissenting). Justice Marshall illustrated his argument with a "telling example, offered by Judge Newman when he was a United States Attorney."

I recently had occasion to discuss $\mid$ Brady| at a PLI Conference in New York City before a large group of State prosecutors ... 1 put to them this case: You are prosecuting a bank robbery. You have talked to two or three of the tellers and one or two of the customers at the time of the robbery. They have all taken a look at your defendant in a line-up, and they have 
Justice Marshall's view of the "realities of criminal practice" would appear to have a firm grounding in research on "cognitive conservatism," research which consistently shows that individuals are resistant to changing an existing view of facts and, consequently, try to incorporate new information in a way that confirms the pre-existing view. ${ }^{54}$ If Justice Marshall's view is correct, it may well be that most prosecutors who actually went through the thought process depicted in the monologue bubble would, in their own minds, ultimately conclude that the impeaching evidence did not generate a realistic probability of reasonable doubt. If the prosecutor chose to disclose the evidence, then, she would be doing so to "to be on the safe side," rather than out of a belief that disclosure was constitutionally required. Because of his concerns that prosecutors would have difficulty engaging in such a dichotomous thought process, Justice Marshall advocated a materiality standard that did not require the prosecutor to assess the likelihood that the evidence would undermine a guilty verdict.

But even if Justice Marshall underestimated most prosecutors' abilities to overcome the cognitive dissonance inherent in the Bagley standard, the scenario underscores how high the materiality bar has been placed. To both trigger pretrial Brady disclosure and remain ethical, the prosecutor simultaneously must believe that she possesses exculpatory evidence that "could reasonably be taken to put the whole case in such a different light as to undermine confidence in [a guilty] verdict," strength of the exculpatory evidence. Such a case is likely to be a rare one, and, of course, if Justice Marshall's psychoanalysis of prosecutors is correct, they will also need to possess the self-enlightenment necessary to avoid rationalizing (not necessarily out of conscious bad faith) that the evidence really is not so exculpatory as to make it probable that a jury would find a reasonable doubt.

Thus, while we can find a scenario where prior to trial a prosecutor can be both ethical and disclose "true" Brady evidence, the scenario is a narrow one. And even in that situation, discovery of evidence so exculpatory that its "suppression ... [would] portend such an effect on a trial's outcome as to destroy

said, "This is the man." In the course of your investigation you also have found another customer who was in the bank that day, who viewed the suspect, and came back and said, "This is not the man."

The question I put to these prosecutors was, do you believe you should disclose to the defense the name of the witness who, when he viewed the suspect, said "that is not the man"? In a room of prosecutors not quite as large as this group but almost as large, only two hands went up. There were only two prosecutors in that group who felt they should disclose or would disclose that information. Yet 1 was putting to them what I thought was the easiest case-lhe clearest case for disclosure of exculpatory information! Id. at 697 (citing J. Newman, A Panel Discussion before the Judicial Conference of the Second Judicial Circuit (Sept. 8, 1967), reprinted in Discovery in Criminal Cases, 44 F.R.D. 48I, 500-0I (1968)).

54. See Donald C. Langevoort, Where Were the Lawyers? A Behavioral Inquiry Into Lawyers' Responsibility for Clients' Fraud, 46 VAND. L. REV. 75, 100-01 (1993) (examining how cognitive conservatism can impede a lawyer's ability to recognize client fraud).

55. Kyles, 514 U.S. at 419. 
confidence in its result," ${ }^{, 56}$ may start to bring the prosecutor uncomfortably close to pursuing a prosecution where she entertains significant doubts as to the defendant's guilt. Most importantly, what becomes evident is that the Brady materiality standard when applied in the pre-trial discovery context is in serious tension with Brady's very idea of prosecutors pursuing "justice" rather than "victory:" the closer we come to finding that certain evidence is sufficiently exculpatory under Brady that it must be turned over, the closer we come to finding that the next ethical step is not disclosure, but dismissal of the charges. If the standard for materiality is this high, then it should be of little wonder-and we in fact should be pleased-that Brady triggers relatively little pre-trial discovery.

At this point, let me confess to having engaged in a bit of rhetorical gamesmanship. I am not seriously suggesting that prosecutors who turn over evidence under the auspices of Brady should be investigated by the state ethics commissions. Quite to the contrary, a prosecutor turning over exculpatory evidence is likely to feel that she should be heralded for acting in a highly ethical manner. I would suggest, however, that the vast majority of the material turned over in these situations is what the Strickler Court labeled "so-called" Brady material: that is, evidence which the prosecutor believes could be seen as exculpatory and therefore discloses the evidence to be on the safe side or out of ethical considerations (or both), bui which the prosecutor does not actually believe could objectively undermine confidence in a guilty verdict if not revealed. ${ }^{57}$ In turning over such evidence, then, the prosecutor is doing so as a matter of judgment and ethical duty rather than out of a constitutional obligation.

Indeed, despite its constitutional stinginess in defining materiality, the Court has in various ways actively encouraged the turning over of "so-called" Brady evidence. For although the Court has carefully distinguished between "true" and "so-called" Brady evidence for remedial purposes, it also has been cognizant of the difficulties that it created by crafting a pre-trial disclosure obligation based on a post-trial conclusion that the evidence would have created a reasonable

56. Id. at 439.

57. As a small sliver of anecdotal evidence, during the year that I served as a Special Assistant United States Altorney, I came across what the Strickler Court would now label "true" Brady evidence on only two occasions (this hindsight assessment assumes, of course, that I am accurately overcoming any cognitive dissonance). In one case, after the exonerating evidence came to light, the charges were dismissed based on a government motion for dismissal. In the other case, the Brady evidence came to light mid-trial and essentially matched the second scenario described above (i.e., I strongly still believed that the defendant was guilty, but I could also see how the evidence might make the jury doubt a key witness's testimony); the defense attorney made effective use of the evidence on cross-examination and the jury hung. During that year, however, I generally did not draw a distinction between "true" and "so-called" Brady, in part because Strickler had not yet been decided, and in part because the section in which I worked strongly endorsed the turning over of any evidence of an exculpatory nature. As a matter of course, therefore, I turned over evidence which we might now term "so-called" Brady evidence but which was not constitutionally compelled. Although beyond the scope of this essay, my observations during that year strongly confirmed the idea that the norms and expectations of a prosecutor's office will influence the behavior of its lawyers beyond the strict letter of the law. Cf. W. Bradley Wendel, Nonlegal Regulation of the Legal Profession: Social Norms in Professional Communities, 54 VAND. L. REV. 1955 (2001). 
probability that the outcome would be different. In Agurs, for example, the Court acknowledged that "there is a significant practical difference between the pretrial decision of the prosecutor and the post-trial decision of the judge" but then advised that "the prudent prosecutor will resolve doubtful questions in favor of disclosure."

Twenty years later, the Court dispensed similar advice but in stronger rhetorical terms. In Kyles, the State requested an even higher materiality standard than the Bagley standard, arguing that it is " 'difficult ... to know' from the 'perspective [of the prosecutor at] trial ... exactly what might become important later on." ${ }^{59}$ With a stern lecturing tone, the Court strongly rejected the State's argument for more "leeway" in deciding whether to disclose evidence:

.... At bottom, what the State fails to realize is that, with or without more leeway, the prosecution cannot be subject to any disclosure obligation without at some point having the responsibility to determine when it must act .... Unless, indeed, the adversary system of prosecution is to descend to a gladiatorial level unmitigated by any prosecutorial obligation for the sake of truth the government simply cannot avoid responsibility for knowing when the suppression of evidence has come to portend such an effect on a trial's outcome as to destroy confidence in its result.

This means, naturally, that a prosecutor anxious about tacking too close to the wind will disclose a favorable piece of evidence .... This is as it should be. Such disclosure will serve to justify trust in the prosecutor as "the representative ... of a sovereignty ... whose interest ... in a criminal prosecution is not that it shall win a case, but that justice shall be done." And it will tend to preserve the criminal trial, as distinct from the prosecutor's private deliberations, as the chosen forum for ascertaining the truth about criminal accusations. ${ }^{60}$

The Court's solution, therefore, for the prosecutor's difficulties in applying a "result-affecting test" before the result is known has been to cheerlead "the prudent prosecutor" to disclose evidence and to give a warning scowl to the prosecutor who would "tack ... too close to the wind." ${ }^{2}$

The Court's holdings and rhetoric thus present a somewhat curious and conflicted view of Brady's core values. The Court appears to want prosecutors to view themselves as under an obligation to turn over "so-called" Brady, implying that on some level it does perceive the turning over of such material as necessary

58. Agurs, 427 U.S. at 108.

59. Kyles, 514 U.S. at 438 .

60. Id. at $439-40$ (citation omitted).

61. United States v. Coppa, 267 F.3d 132, 143 (2d Cir. 2001) (recognizing that the Brady disclosure standard requires "[a|n assessment . . best made after a trial is concluded.").

62. Kyles, 514 U.S. at 439. 
for ensuring fair trials. At the same time, the Court is unwilling to place a constitutional imprimatur on the pre-trial disclosure of such evidence because it does not want to provide a post-trial remedy unless it is convinced that serious doubts exist as to the defendant's guilt. Brady's inability to gain a firm constitutional foothold as a pre-trial right, therefore, can in part be attributed to the Court's concerns with post-conviction relief, resulting in a somewhat odd and circular spectacle: a pre-trial obligation that is defined through speculation on a post-trial result, a result which itself ultimately may be influenced by the pre-trial decision of whether or not to disclose.

\section{THE REALITIES OF BRADY AS A DISCOVERY DEVICE}

Once we unmask the realities of how Brady matches up with the ethical prosecutor's duties, the limits of Brady's pre-trial reach become apparent. While we all can readily state the materiality test for Brady, it may still have come as something of a surprise to actually apply the standard in a pre-trial context. I suspect this surprise results because many lawyers, judges and law professors still reflexively tend to think of Brady in "so-called" Brady terms rather than in "true" Brady terms. This tendency is perhaps unintentionally reinforced by the judiciary's proclivity for speaking of Brady in language such as: "Brady does not require a prosecutor to divulge every scintilla of evidence that might conceivably inure to a defendant's benefit." ${ }^{, 63}$ While true, this type of statement also carries the implication that Brady has a fairly far reach and that the courts must, therefore, guard against letting its tendrils spread so wide that it is used to reach "every scintilla of [favorable] evidence." In reality, though, as the Strickler Court's expression of the distinction reminds us, far from threatening to sweep every "shred of [favorable] evidence", within Brady's constitutional scope, the doctrine's pre-trial discovery reach is really quite limited.

Moreover, Brady's doctrinal limitations as a pre-trial discovery mechanism are magnified by the realities of criminal practice. Close to ninety percent of all cases on both the federal and state levels are resolved through guilty pleas, and the Court has indicated that Brady will have little, if any, role to play during plea bargaining. In United States v. Ruiz, ${ }^{65}$ the Court unanimously reversed a Ninth Circuit case which had held that Brady gave a defendant the right to disclosure of material impeachment information prior to entering a guilty plea. ${ }^{66}$ While the Supreme Court cautiously did not declare that Brady could never apply to a

63. United States v. Reyes, 270 F.3d 1158, 1166 (7th Cir. 2001) (quoting Lieberman v. Washington, 128 F.3d 1085, 1092 (7th Cir. 1997)).

64. Smith v. Sec'y of N.M. Dep't of Corr., 50 F.3d 801, 823 (10th Cir. 1995).

65. 122 S.Ct. 2450 (2002).

66. Because the Ninth Circuit concluded that Brady applied to plea agreements, it proceeded to find that the government could not lawfully require defendants to waive their right to Brady information. United States v. Ruiz, 24l F.3d 1157, 1167-69 (9th Cir. 2001). 
guilty plea, ${ }^{67}$ the Court also repeatedly emphasized that Brady was a trial-related right distinct from the decision to plead guilty. ${ }^{68}$ Consequently, the fact that nine out of ten cases are resolved by guilty pleas ensures that Brady plays a minimal role in triggering prosecutorial disclosure of exculpatory evidence. Indeed, even in the small percentage of cases that do proceed to trial, the courts have understood Brady as not requiring disclosure until the trial itself, unless the failure to disclose earlier rendered the trial unfair. ${ }^{69}$

Once Brady's development as a constitutional law doctrine is coupled with the realities of criminal practice, it should not be surprising that Brady has not generated a large amount of pre-trial discovery. Assuming the case even proceeds to trial, it will be-and perhaps ethically should be-a rare case where a prosecutor will possess evidence that she believes objectively raises serious questions about the defendant's guilt and yet decides to still pursue a conviction at trial. The Court, in other words, has defined "true" Brady in such a way that prosecutors in their daily practice should not be consistently finding such material in the files of the cases that they are taking to trial.

It is important, therefore, to recognize Brady as less of a discovery mechanism and as more of a post-trial due process safety check where information surfaces after trial that exculpatory evidence was suppressed. ${ }^{70}$ Perhaps Brady's most important pre-trial function is that it stresses the prosecutor's responsibility for and the need to be aware of all evidence within the government's possession. ${ }^{71}$ By

67. The majority expressly noted in its opinion that the plea agreement in issue had obligated the government to turn over "any information establishing the factual innocence of the defendant" and that the evidence at issue was impeachment evidence. Ruiz, $122 \mathrm{~S}$.Ct. at 2455-56. One possible inference is that Brady might apply to guilty pleas if a plea agreement did not contain a rough equivalent to Brady or if the exculpatory evidence at issue more directly proved the defendant's innocence than impeachment information. Id. at 2457 (Thomas, J., concurring). This possible interpretation led Justice Thomas to write a special concurrence to clarify his view that Brady is "not implicated at the plea stage regardless." Id. See also Matthew v. Johnson, 201 F.3d 353 (5th Cir. 2000) (suggesting that Brady may not apply to guilty pleas).

68. The majority opinion used italics not once but twice in expressing the view that Brady impeachment material relates to "the fairness of a trial, not . . . to whether a plea is voluntary." Ruiz, $122 \mathrm{S.Ct}$. at 2455 . "[T] he need for this information is more closely related to the fairness of a trial than to the voluntariness of the plea." Id. at 2457.

69. See BENNETT L. GERSHMAN, PROSECUTORIAL MISCONDUCT $\$ \S 5: 13-: 15$ (2d ed. 2000).

70. Possible Brady violations can surface in a variety of ways, ranging from an ethical prosecutor learning of a problem and disclosing it, Imbler v. Pachtman, 424 U.S. 409, 413 (1976) (prosecutor revealed newly discovered evidence "from a belief that 'a prosecuting attorney has a duty to be fair and see that all true facts, whether helpful to the case or not, should be presented"'), to the defense filing a Freedom of Information Act request, United States v. Bagley, 473 U.S. 667 (1985) (FOIA request uncovered contracts with government witness which contradicted pre-trial claims that no "deals, promises or inducements" had been made).

71. See, e.g., Kyles, 514 U.S. at 437 . The Court's encouragement of voluntary disclosure coupled with its expansive view of what is exculpatory offers defense counsel an opportunity to seize the initiative by filing Brady-Kyles motions specifically requesting evidence that might be exculpatory in their case. Kyles suggests that defense counsel should think broadly, citing evidence like that at issue in Kyles: evidence calling into question the credibility of non-witnesses, internal police documents providing the basis for claiming the police were negligent in their investigation, or evidence comparable to the list of license numbers of the cars in the crime scene's parking lot. See William S. Geimer, Pretrial Kyles, 1998 Annual Criminal Law Seminar (Virginia Trial Lawyers Association) (on file with author). While specific requests are encompassed with Bagley's onesize-fits-all materiality standard, they still are more likely to yield a finding of materiality because they put the prosecutor on notice that the defendant views the information as potentially exculpatory. Bagley, 473 U.S. at 
making the prosecutor responsible for all of the government's evidence, Brady provides legal leverage to both courts and prosecutors to ensure that the police or investigating agencies have fully revealed to the prosecutor both the favorable and unfavorable evidence that they have collected. Because the evaluation of evidence as "material" under Brady rests with the prosecutor, she is constitutionally obligated to ensure that the police and other investigating bodies are showing her all of the evidence that they have gathered, whether or not the police believe the evidence to be materially exculpatory. In this sense, Brady does enhance pre-trial discovery by making the police subject to a due process obligation to provide all evidence and information to the prosecutor so that she in turn can fulfill her constitutional obligations. ${ }^{72}$

Otherwise, Brady's primary impact on pre-trial discovery would seem to be the sub-constitutional effect of encouraging prosecutors to turn over "so-called" Brady evidence. From this perspective, while declining to give constitutional status to the ABA standards for prosecutorial disclosure, Brady can be seen as helping to foster an atmosphere consistent with their compliance. To the extent that this sub-constitutional side effect exists, it is laudatory, and at least one survey indicates that prosecutors often do voluntarily fill the void left by formal discovery obligations. ${ }^{73}$

What cannot be known without further study, of course, is whether prosecutors are turning over "so-called" Brady material with the same frequency that they would if they were under a formal constitutional obligation. Certainly the most significant difference is that a prosecutor who declines to disclose "so-called" Brady material knows that the defendant will not have a remedy, even if the noncompliance constitutes a serious ethical violation. ${ }^{74}$ While many prosecutors are likely to turn over "so-called" Brady to be on the safe side and out of a sense of ethical obligation, cases like Strickler v. Greene send the message that even powerful exculpatory evidence is unlikely to cause the prosecutor to run afoul of Brady. In Strickler, the majority went so far as to say that " $[\mathrm{t}]$ he District Court [which had found a Brady violation based on 'potentially devastating

$682-83$

72. See generally Robert Hochman, Brady v. Maryland and the Search for Truth in Criminal Trials, 63 U. CHI. L. REV. 1673, 1700-05 (1996).

73. See, e.g., Wm. Bradford Middlekauff, What Practitioners Say About Broad Criminal Discovery Practice, CRIM. JUST., Spring 1994, 14, 55 (stating that seventy-six percent of responding Assistant U.S. Attorneys in a $1984 \mathrm{ABA}$ survey stated that they provide extensive discovery beyond what is required by the Federal Rules of Criminal Procedure and forty-two percent adopt an open-file policy). See also Laurie L. Levenson, Working Outside the Rules: The Undefined Responsibilities of Federal Prosecutors, 26 FORDHAM URB. L.J. 553, 562-63 (1999) (establishing how prosecutors have ethical obligations to fill in the "gaps" in areas such as discovery).

74. Unless state law provides for a new trial where failure to disclose falls shy of a Brady due process violation, the defendant will not be entitled to a new trial at which he can use the exculpatory evidence. Even the chances of a disciplinary proceeding against the prosecutor for violating the ethics rules are slim. One commentator found that "disciplinary charges have been brought infrequently and meaningful sanctions rarely applied" against prosecutors for violating the ethical rules governing discovery. Richard A. Rosen, Disciplinary Sanctions Against Prosecutors for Brady Violations: A Paper Tiger, 65 N.C. L. REV. 693, 697 (1987). 
impeachment material' that had not been disclosed] was surely correct that there is a reasonable possibility that either a total, or just a substantial, discount of the [eyewitness's] testimony might have produced a different result, either at the guilt or sentencing phases," but proceeded to deny relief because the evidence did not establish "a reasonable probability of a different result.","

If Brady is simply a tool for appellate courts to double-check the guilt of the defendant where suppressed evidence comes to light after conviction, then the Court's fashioning of Brady seems appropriate and any turning over of "socalled" Brady evidence is merely ethical icing on the due process cake. But this, of course, brings us back to the original point of the essay: making transparent that Brady is not a discovery doctrine but instead a means of remedying police and prosecutorial misconduct or, in certain cases, unintentional but highly prejudicial non-disclosures. And we also should not forget that an alternative view of the "Brady ideal" was possible: an interpretation that saw Brady as a pretrial right aimed at ensuring that a criminal trial is a full adversarial airing of evidence before the jury.

\section{FINAL THOUGHTS ON BRADY AND DISCOVERY}

When the Court was first crafting the materiality standard, Justice Marshall expressed a view that very well might have led Brady to assume more of a superhero status when it came to pre-trial discovery. In Agurs, Justice Marshall first began to voice his view that the Court's materiality standard was frustrating Brady's purposes. ${ }^{76}$ By the time of Bagley, he had come to believe that a prosecutor should have to "turn over to the defendant, all information known to the government that might reasonably be considered favorable to the defendant's case." $\mathrm{He}$ advocated the "reasonably favorable" standard because he believed that the due process obligation should focus on ensuring that a defendant had all of the material necessary to effectively mount a defense to the State's use of the prosecutorial power at trial. ${ }^{78}$ In other words, what the Strickler Court termed "so-

75. Strickler, 527 U.S. at 291.

76. See Agurs, 427 U.S. at 119 (Marshall, J., dissenting) (stating that the defendant should be entitled to a new trial if he shows "there is a significant chance that the withheld evidence, developed by skilled counsel, would have induced a reasonable doubt in the minds of enough jurors to avoid a conviction.").

77. Bagley, 473 U.S. at 695-96 (Marshall, J., dissenting).

78. Once the prosecutor suspects that certain information might have favorable implications for the defense, either because it is potentially exculpatory or relevant to credibility, I see no reason why he should not be required to disclose it. After all, favorable evidence indisputably enhances the truth-seeking process at trial. And it is the job of the defense, not the prosecution, to decide whether and in what way to use arguably favorable evidence. In addition, to require disclosure of all evidence that might reasonably be considered favorable to the defendant would have the precautionary effect of assuring that no information of potential consequence is mistakenly overlooked. By requiring full disclosure of favorable evidence in this way, courts could begin to assure that a possibly dispositive piece of information is not withheld from the trier of fact by a prosecutor who is torn between the two roles he must play. A clear rule of this kind, coupled with a presumption in favor of disclosure, also would facilitate the 
called" Brady material would have become "true" Brady under Justice Marshall's standard, and failure to disclose it would have required reversal unless the prosecutor could satisfy the harmless error standard of Chapman v. California. ${ }^{79}$

The "reasonably favorable" standard, therefore, almost certainly would have led Brady to play a far greater role as an avenue of pre-trial discovery, in part because it adopts a forward-looking pre-trial perspective instead of using the current post-conviction reversal standard. Rather than requiring the prosecutor to step into the shoes of a hypothetical juror and speculate whether the evidence would cause a juror to have a reasonable doubt in a yet-to-be-heard case, Marshall's standard would have placed the prosecutor in the far more familiar role of a lawyer and asked a far easier question: can I see how, if I were the defense attorney, I would be able to use this information to advance my client's argument for acquittal? Like all lawyers, prosecutors are trained to look at how evidence can be used to poke holes in their case so that they can anticipate how to respond to any weaknesses. By asking the prosecutor to engage in this familiar exercise as the means of fulfilling her Brady duties, the "reasonably favorable" query would thus have presented a standard that would have been far easier for the prosecutor to apply prior to trial. ${ }^{80}$

Such an inquiry would also relieve the ethical tension that this essay has argued underlies the Bagley standard. As we have seen, Bagley requires the prosecutor to achieve a state of cognitive separation where she can simultaneously recognize that a piece (or pieces) of evidence objectively can create a reasonable doubt for the jury while still believing that the case warrants prosecution. The "reasonably favorable" standard, by contrast, would not require the prosecutor to obtain this Zen-like state of simultaneously harmonizing objective and subjective beliefs, but only would require that she understand how the evidence could be viewed by the defense as helpful to her case; in other words, under Marshall's standard, Brady would be triggered far before a prosecutor would have to engage in any serious ethical questioning of whether she should still be pursuing the case because the exculpatory evidence exists. And, as we have seen, part of Justice Marshall's argument for the easier-tosatisfy "reasonably favorable" standard was his belief that the psychological realities of a prosecutor's practice would render it difficult for a prosecutor to engage in the cognitive separation that the Bagley standard now asks of prosecutors.

ld. at 698 .

prosecutor's admittedly difficult task by removing a substantial amount of unguided discretion.

79. Id. at 704 (citing Chapman v. California, 386 U.S. 18 (1967)). Chapman would require "revers[al] unless it is clear beyond a reasonable doubt that the withheld evidence would not have affected the outcome of the trial." Id. Justice Marshall acknowledged the criticism that the harmless error standard could be applied so as to make little practical difference, but he believed that by making clear that the duty to disclose extended to "all" favorable evidence and not just "some," his standard would engender greater disclosure. $I d$. at 705.

80. Justice Marshall argued that this standard acknowledged that "[n]o prosecutor can know prior to trial whether such evidence will be of consequence at trial; the mere fact that it might be, however, suffices to mandate disclosure." Id at 702-03. 
Whether the "reasonably favorable" standard ultimately would have been a wise constitutional rule is open to debate on a variety of constitutional and policy grounds. ${ }^{81}$ In a number of constitutional areas, not just with Brady, the Supreme Court deliberately has "underenforce[d]" constitutional rights because of institutional concerns. ${ }^{82}$ Beyond debate, however, is the conclusion that Justice Marshall's approach would have brought Brady far closer to superhero status in the discovery context.

Brady remains an important constitutional doctrine and, indeed, a constitutional superhero, in certain contexts: the doctrine can ensure that a defendant has a postconviction remedy if police or prosecutorial misconduct is uncovered, ${ }^{83}$ even if the suppression was inadvertent. ${ }^{84}$ Nor can one downplay the importance of Brady's moral message to every government actor that they are responsible not only for collecting evidence of guilt, but also for being vigilant as to the existence of exonerating evidence. As this essay has attempted to highlight, however, it also is important to keep in mind that when it comes to debating whether defendants have adequate access to discovery prior to trial, Brady's superhero credentials are distinctly human.

81. Canada's experience with prosecutorial discovery offers an interesting counter-example to the United States Supreme Court's chosen route. Canada adheres to a standard of disclosure more closely attune to Justice Marshall's approach, requiring "disclosure of all relevant information" with relevance being defined as having a reasonable probability that it will be useful to the accused; no distinction, however, is made between inculpatory and exculpatory evidence. See Regina v. Stinchcombe [1991] S.C.R. 326. For a defense of the United States Supreme Court's "reasonable probability" standard, see Corinne M. Nastro, Strickler v. Greene: Preventing Injustice By Preserving the Coherent 'Reasonable Probability' Standard to Resolve Issues of Prejudice in Brady Violation Cases, 60 MD. L. REV. 373 (2001).

82. Robert C. Post \& Reva B. Siegel, Equal Protection by Law: Federal Antidiscrimination Legislation After Morrison and Kimel, 110 YAl.E L.J. 441,467 (2000); Lawrence Gene Sager, Fair Measure: The Legal Status of Underenforced Constitutional Norms, 91 HARV. L. REV. 1212, 1218 (1978).

83. See, e.g., In re an Investigation of W. Va. State Police Crime Lab., Serology Div., 438 S.E.2d 501 (W. Va. 1993) (relying on Brady to provide system-wide relief where crime lab investigator engaged in widespread misconduct that was not discovered until after numerous trials).

84. Brady, 373 U.S. at 87. 